\title{
O PENSAMENTO GEOGRÁFICO NA OBRA MACUNAÍMA: "o herói sem nenhum caráter"
}

\author{
Prof. Dr. Antônio Carlos Vitte \\ Bolsista Produtividade CNPq \\ Programas de Pós graduação em Geografia UNICAMP \\ IG-Unicamp. CP 6152, CEP 13083-970 - Campinas - SP, Brasil \\ Tel: (55 19) 3521.4653 - vitte@uol.com.br \\ Giuliano Coutinho \\ giulianocoutinho@yahoo.com.br
}

\begin{abstract}
RESUMO
O presente trabalho examina o pensamento geográfico na obra Macunaíma de Mário de Andrade. A premissa é que o espaço geográfico enquanto representação de uma sociedade em uma determinada época pode congregar as discussões sobre a nacionalidade e a construção de uma nação. Macunaíma representa uma proposta de nação, cujos fundamentos estão erigidos na cultura e na natureza do Brasil. A tese em Macunaíma para o desenvolvimento do Brasil fundamenta-se em um projeto des-geografização, ou seja, era necessário o rompimento dos arquipélagos regionais, que representavam um entrave para a construção da nação. Em Mário de Andrade, o território surge como produto da relação e da mediação entre a cultura e a natureza, relação necessária para o desenvolvimento do Brasil.
\end{abstract}

Palavras-chaves: Pensamento Geográfico; Macunaíma; Arquipélagos Regionais; Cultura; Natureza; Nação.

\begin{abstract}
This paper examines the geographical thought in Mário de Andrade's novel Macunaíma. Geographical space is taken as a premise representation of society in a specific time in order to bring together discussions on nationality and national construction. Due to the foundations erected in the culture and nature of Brazil, Macunaíma represents a proposal of nation. Macunaíma thesis for the development of Brazil is based on a de-geographic project necessary to break the "regional islands" that represent an obstacle for the national building. According to Mario de Andrade territory is a relational product of mediation between culture and nature necessary for the development of Brazil.
\end{abstract}

Key words: Culture, Geographic Thought, Macunaíma; Nature, Nation, Regional Island.

\section{RESUMEN}

Este documento examina el pensamiento geográfico en la labor Macunaíma Mario de Andrade. La premisa es que el espacio geográfico como una representación de una sociedad en un momento determinado puede reunir a los debates de la nacionalidad y la construcción de la nación. Macunaíma se propone como una nación cuyos cimientos se erigen en la cultura y la naturaleza en el Brasil. La tesis de Macunaíma de desarrollo de Brasil se basa en un proyecto-des geographisation, es decir, era necesario romper los archipiélagos regionales, lo que representa un obstáculo para la construcción de la nación. De Andrade, la zona es tanto producto de la relación y la mediación entre la cultura y la naturaleza, el respeto por el desarrollo de Brasil.

Palabras clave:

Palabras-Claves: El pensamiento geográfico; Macunaíma; Archipiélagos Regional, Cultura, Naturaleza, La Nación.

\section{INTRODUÇÃO}

A década de 1920 é considerada a década da transição política, econômica, social e cultural (LAUHERTA, 1992; DE LORENZO E COSTA, 1997; OLIVEIRA, 1997). É um período de uma enorme multiplicidade de forças, a da oligarquia cafeeira, do empresariado industrial, do operariado urbano e, da intelectualidade, que produto e desejosa de mudanças e transformações no país irão tematizar a questão da nação e da identidade nacional brasileira (ORTIZ, 2006).

Ao problematizarem a questão da identidade nacional brasileira, estão implícita ou explicitamente, colocando em questão o desenvolvimento territorial do capitalismo no Brasil. Neste processo muitas teorias e modelos serão utilizados, como por exemplo, as que debatiam a questão racial e o seu sincretismo no Brasil (ORTIZ, 2006), que para muitos intelectuais que seria a principal causa do atraso brasileiro. Foi o caso de Oliveira Vianna e Sílvio Romero, enquanto que Euclides da 
Cunha e mesmo Gilberto Freyre, viam na miscigenação a alternativa para se construir o Brasil. (SCHWARZ, 1997; ORTIZ, 2006).

Como pano de fundo deste debate público está a questão do território e de sua integridade, as diferenciações culturais em termos regionais, assim como a questão da natureza e sua influência nas perspectivas de desenvolvimento do capitalismo.

A década de 1920 é um dos momentos da história brasileira em que o espaço (MORAES, 1988) aparece fortemente tematizado e será utilizado pela elite intelectual, assim como pela elite política e econômica como elemento aglutinador de uma proposta de Estado Nacional e de construção da Nação. Apesar das propostas e dos anseios de modernização e até mesmo de transformação da realidade brasileira, o modus operandi para a construção da unidade e da identidade nacional ainda estará vinculada a matriz ibérica (ARRIGHI, 1993), em que o espaço é um elemento importante para a resolução dos problemas políticos de modernização do território e ao mesmo tempo um instrumento chave para a construção da Nação por meio da intervenção do Estado Nacional.

É no contexto de uma revolução passiva (VIANNA, 2001) com suas características sociais, políticas e culturais que estará inserida a semana de arte moderna de 1922, que catalizará todo o processo de discussão sobre o Brasil e a identidade nacional brasileira. Ao contrário daqueles que viam na importação e na metamorfose das teorias e modelos europeus implantados no Brasil, Mário de Andrade (1893-1945) a partir de estudos sobre o folclore brasileiro e de suas viagens etnográficas pelo litoral brasileiro e pela Amazônia irá pautar da discussão sobre a identidade nacional, a partir de uma história própria, onde Macunaíma, o herói, é o produto histórico da fusão da natureza e da cultura no território nacional.

O objetivo deste artigo é apresentar a proposta de Mário de Andrade para a construção da identidade nacional brasileira, por meio de Macunaíma, enquanto produto de uma relação entre história territorial, história da natureza, e dinâmicas culturais regionais, rompendo ao mesmo tempo com os arquipélagos regionais que ainda eram as matrizes espaciais de boa parte da intelectualidade brasileira..

\section{O PENSAMENTO GEOGRÁFICO E A CONSTRUÇÃO DA IDENTIDADE BRASILEIRA}

Paralelamente às mudanças tratadas na primeira parte deste trabalho, os intelectuais dessa época começaram a discutir o Brasil sob um novo ângulo. A forma de pensar a sociedade e o território brasileiros pela tradicional oligarquia agrária não correspondia às transformações na estrutura geográfica do território nacional, tampouco na forma de encará-la. Essa visão representava uma perspectiva de interpretação da realidade brasileira dissimulada e fantasiosa que podia ser encarada como a expressão da consciência da oligarquia cafeeira alojada no poder (LAFETÁ, 2000).

Tal interpretação tem sua origem durante o século XIX, notadamente a partir da segunda metade, quando se tentou conceber um sentido de ser brasileiro e até mesmo de recontar ou de construir uma história nacional. Nesse sentido, o romantismo - além do IHGB, fundado em 1838 - contribuiu eficazmente a esse papel, através de obras que procurassem estabelecer uma nacionalidade brasileira. ${ }^{1}$ No elenco das obras que procuraram executar essa tarefa, talvez o exemplo mais significativo seja o Guarani, de José de Alencar. Seu conteúdo é marcado pelo mito fundador da brasilidade, no qual o cruzamento entre o índio (idealizado) e a bela portuguesa representaria a origem da raça brasileira (MORAES, 2002a; ORTIZ, 2006). Contudo, a figura do negro está ausente, o que denota um estreito ângulo de interpretação da realidade brasileira. Ademais, nesse momento a figura do negro estava muito mais associada como mão-de-obra escrava e, por sua vez, privado de qualquer cidadania (ORTIZ, 2006).

O que caracterizou o mote ideológico desse período, desde a Independência (1822) e adentrando nos anos seguintes à Proclamação da República (1889) foi o da civilização (MORAES, 2002a). Essa máxima, central no pensamento brasileiro do período, tinha como um dos pressupostos construir 
o país. Além de sedimentar uma visão de projeto nacional entre as elites (bastante regionalizadas), legitimava a ação do Estado brasileiro como agente central dessa construção; a coesão entre esses elementos se traduziria na identidade e nacionalidade brasileiras (MORAES, 2002b). De tal modo que no final do século XIX procurava-se "insistentemente definir o fundamento do ser nacional como base do Estado brasileiro" (ORTIZ, 2006, p. 130). Nesse sentido, o povo atenderia a esses interesses segundo as necessidades de ocupação do território, pois era vista como ferramenta necessária à criação do país. Logo, ocuparia um papel "secundário" perante o poder estatal.

Por sua vez, a distribuição espacial da população asseguraria a integridade do território, posto que nesse momento apresentava-se de maneira bastante frágil. Porém, a grande questão entre as elites em torno da execução desse projeto era: a que povo será confiado a tarefa de construir o país?. De tal maneira que a política imigratória nesse período atuou como um dos meios para sair do impasse, além de políticas voltadas às comunidades indígenas (MORAES, 2002b). Ao se referirem ao imigrante, as elites aludiam ao branco europeu. Assim, para construir o país - sob avaliações etnocêntricas - era necessário "substituir" a população, que pode ser lida como "branqueamento". No limite, a situação apresentava-se da seguinte maneira:

As concepções do Brasil como sendo o seu território, e da ocupação do espaço como a construção do país, estão entre estes juízos reificados no pensamento das elites brasileiras no período enfocado. (MORAES, 2002b, p.120).

Essa concepção predominante de Brasil permaneceu até o final do século XIX e início do XX. Porém, à medida que esses discursos prolongaram-se nesse período, uma outra geração a superou, substituindo essa forma de pensar por outras, reificando outras avaliações. Nesse sentido, após alguns anos da virada do século, foi ocorrendo uma gradual alteração na base do pensamento brasileiro, marcado por outras concepções como, por exemplo, a cientificista.

Conforme Moraes (2002b):

Uma postura cientificista vai aos poucos hegemonizando-se e acaba por fazer a ponte entre as velhas instituições do saber e as novas agências de difusão de um novo ideal de ciência, ao qual se associa a idéia de modernidade. (MORAES, 2002b, p. 121).

Assim, a compreensão da realidade brasileira foi adquirindo contornos claramente cientificistas. A leitura das teorias evolucionistas e racistas européias por um amplo corpo da intelectualidade brasileira conduziu-o na tentativa de buscar, nesse momento, explicações científicas para as condições brasileiras, concebidas sob o estigma do "atraso". Entretanto, há um aspecto peculiar: a assimilação dessas idéias em solo brasileiro ocorreu num momento em que estas já apresentavam sinais de questionamento e decadência na Europa (MORAES, 2002b). Todavia, foram essas teorias que compuseram a base epistemológica brasileira no fim do século XIX e nas primeiras décadas do século passado.

A respeito dessas teorias, Diniz Filho (2002) observa:

... a inflexão cultural ocorrida no Brasil do princípio do século XX se deu a partir da importação de teorias de gênese e natureza bastante diversas, que incluíam o positivismo de Augusto Comte e de vários teóricos filiados a esta corrente de pensamento, como Ratzel e Gobineau; o evolucionismo social de Herbert Spencer; os teóricos da psicologia coletiva, como Tarde e Le Bom; o intuicionismo de Bergson; entre outras. (DINIZ FILHO, 2002, p. 11).

Essas teorias forneceriam, de algum modo, um suporte para buscar explicações a respeito das condições nas quais se encontravam a sociedade e o espaço brasileiros. A assimilação desses fundamentos científicos gerou um amplo debate entre os intelectuais que desejavam trazer à tona as razões para revelar o sentido de ser brasileiro e a questão da própria identidade. Se durante o 
século XIX esses temas eram explicados à luz da ficção do romantismo, sobretudo, no início do século XX delinearam-se explicações baseadas nesses princípios. ${ }^{2}$

Contudo, o esclarecimento a respeito das condições do Brasil foi marcado pelo amálgama dessas concepções heterogêneas, isto é, pela fusão desses ingredientes culturais antagônicos num só elemento, apesar da sua visível incompatibilidade (DINIZ FILHO, 2002). Assim, o quadro cultural brasileiro durante esse período apresentava-se pela combinação dessas diferentes correntes de pensamento. Em síntese, "a última década do século XIX e as três primeiras do século XX podem ser vistas como uma época de redefinição da identidade nacional” (MACHADO, 1995, p. 309).

Essa redefinição constituiu-se num movimento que atuava em duas frentes: de um lado, uma perspectiva endógena, pautada pela visão acerca da sociedade e espaço brasileiros. Tal visão repousava sobre os atributos físicos do território e as características da população - muitas vezes relacionadas às condições políticas, econômicas e sociais do Brasil. Deste modo, o determinismo exerceu um papel relevante na tentativa de explicar os nexos entre os aspectos naturais e as condições da população. De outro, um ângulo exógeno, que procurava estabelecer um posicionamento do país perante as nações apontadas como "avançadas", ou seja, em relação aos países europeus. Nesse sentido, a teoria evolucionista fornecia o respaldo necessário para a explicação da situação de "atraso" na qual se encontrava o Brasil.

Sob a ótica determinista lançou-se uma visão esperançosa de o Brasil se constituir como grande potência, dada a opulência da natureza e a grandeza do território. Entretanto, em relação à população foram elaboradas duas proposições opostas: por um lado, uma visão otimista, na qual a "população miscigenada era a garantia de um controle eficaz da natureza tropical" (MACHADO, 1995, p.312), por outro, uma visão pessimista, "que contrastava uma natureza generosa com uma população heterogênea, em crescimento desordenado, incapaz de se auto-organizar e de gerir de forma racional o território" (idem). Tanto que foi comum a difusão de valores racistas entre alguns segmentos da sociedade.

Já em relação ao evolucionismo, cujo postulado era a passagem natural do estado de "atrasado" à condição de "avançado", na qual as nações européias eram vistas como exemplares e que todas as nações indubitavelmente atingiriam - de qualquer forma - um dia, através de leis que regulassem todo o processo, a intelectualidade brasileira buscou incessantemente estabelecer as causas do "atraso" e, com isso, corrigi-las no sentido de projetar o caminho necessário para retomar o curso perdido do desenvolvimento, atribuído pela prática do modelo político liberal sancionado pela Constituição de 1891 (DINIZ FILHO, 2002). Em suma, o estabelecimento da "ordem" conduziria mecanicamente ao "progresso".

Sobre o evolucionismo no Brasil, Ortiz (2006) assinala:

Aceitar as teorias evolucionistas implicava analisar-se a evolução brasileira sob as luzes das interpretações de uma história natural da humanidade; o estágio civilizatório do país se encontrava assim de imediato definido como 'inferior' em relação à etapa alcançada pelos países europeus. (ORTIZ, 2006, p. 15).

Na tentativa de superar o sentimento de "inferioridade" urgiu, com isso, a necessidade de pensar o Brasil sob outra perspectiva. Assim, “o papel catalisador que a noção de 'civilização' cumpriu para a antiga mentalidade será agora ocupado pelo conceito de modernização" (MORAES, 2002b, p. 121).

Esse conceito se inscreve, novamente, na concepção de construir o país (MORAES, 2002b). Porém, os contornos dessa ideologia geográfica assumiam outros propósitos. Apesar de equacionar o Brasil novamente no âmbito espacial, desta vez a partir do aparelhamento técnico no território como, por exemplo, a eletrificação, no âmbito dos intelectuais o tema de orientação foi o da "organização da nação". Diretamente relacionado às transformações técnicas, havia o desejo de alcançar uma posição de destaque no cenário internacional, aliado às pretensões de serem modernos. 
De acordo com Lahuerta (1992):

... é compreensível que a pretensão de ser moderno se desloque paulatinamente para o tema nacional, pois desde as atividades preparatórias para a comemoração do 100 anos da Independência, ao medir pelo metro hegemônico nossa situação frente à Europa, o 'atraso' ia se tornando cada vez mais flagrante. (LAHUERTA, 1992, p. 32-33).

É interessante como esse sentimento de "atraso", tomado no sentido de redefinir a nacionalidade e identidade brasileiras, assumiu contornos nitidamente autoritários por alguns intelectuais. ${ }^{3}$ Ademais, as formulações desses pensadores, em sua grande maioria, se valeram das teses deterministas ambientais da Geografia acadêmica européia (DINIZ FILHO, 2002) - na qual o positivismo de Augusto Comte constituía-se como a matriz ideológica principal - para comporem suas concepções nacionalistas. Nesse sentido, as figuras de Azevedo Amaral, Cassiano Ricardo, Menotti Del Picchia, Oliveira Vianna, Plínio Salgado, dentre outros, se propuseram, através de suas obras, estabelecer suas respectivas interpretações sobre a realidade brasileira. ${ }^{4}$ Posteriormente, já na década de 1930, alguns atuaram em movimentos de direita, tais como a Ação Integralista Brasileira, de 1932, ou como ideólogos do Governo Vargas durante o Estado Novo $\left(1937\right.$ - 1945). ${ }^{5}$

Desta forma, o nacionalismo levado a cabo por esse grupo forneceu a legitimidade necessária ao Estado no que tangia aos parâmetros para superar, segundo eles, a situação de atraso econômico e social, além de atribuir a este a responsabilidade pela "construção do país", desta vez nos moldes da modernização. ${ }^{6}$ Além disso, o Estado era visto como o único meio capaz de corrigir e anular a multiplicidade de forças que se davam no seio da sociedade brasileira (DINIZ FILHO, 2002) para, portanto, mirar no futuro a perspectiva do Brasil se compor enquanto povo, ou seja, conforme uma nação (ORTIZ, 2006). De fato, esse sentimento de "organização da nação" importou grandemente nas decisões do Estado, colocando-se como um fator decisivo para a recomposição da unidade.

Segundo Lahuerta (1992):

O resgate de Alberto Torres pela geração de Oliveira Vianna cria - à esquerda e à direita - enorme consenso entre a intelectualidade quanto à necessidade de unificação do país, além de levar às últimas conseqüências a perspectiva de que somente o Estado, sobrepondo-se aos anseios privatistas e 'utilitários' do homem comum, poderia realizar a construção da Nação e a modernização da sociedade. (LAHUERTA, 1992, p. 3).

Entretanto, em relação aos desdobramentos do movimento modernista verificamos que a questão da nacionalidade adquiriu outros contornos. ${ }^{7}$ Se nos momentos iniciais de preparação do modernismo o eixo principal foi o combate ao passado e à elaboração de uma nova estética, após a Semana o fio condutor foi o debate acerca da brasilidade (OLIVEIRA, 1997). E mais: "O modernismo cria[ou] e difunde[iu] a necessidade de identificar a substância do SER brasileiro, denuncia[ou] os conhecimentos/saberes atrasados que impedem[iam] a captação do ser brasileiro e colabora[ou] na elaboração de inúmeros 'retratos do Brasil' (título da obra de Paulo Prado, 1928)" (OLIVEIRA, 1997, p. 191). Nesse sentido, é interessante como o "atraso" é tomado por parte desses intelectuais como justamente a característica básica que torna possível a transformação do país.

Segundo Schwarz (1997):

O desajuste não é visto como vexame e sim com otimismo - aí a novidade - como indício de inocência nacional e da possibilidade de um rumo histórico alternativo, quer dizer, não burguês. Este progressismo sui generis se completa na aposta pela tecnificação: inocência brasileira (fruto de cristianização e aburguesamento apenas superficiais) + técnica $=$ utopia. A idéia é aproveitar o progresso material moderno para saltar da sociedade pré-burguesa diretamente ao paraíso. (SCHWARZ, 1997, p. 37). 
Em relação a Mário de Andrade, esse "desajuste", consubstanciado no otimismo em relação ao país, foi equacionado através de seus estudos sobre o folclore ${ }^{8}$ e nas possibilidades de realizar a arte erudita através da inversão do material folclórico ${ }^{9}$ como o caminho para a superação dos contrastes espaciais e sociais brasileiros. Nesse sentido, a questão da "organização da nação" se deu nele pelo viés cultural, de tal modo que "não foi por acaso que os estudos do folclore se fazem[iam] na direção oposta ao que se denominou na época de exageros do romantismo" (ORTIZ, 2006, p. 37). Essa direção oblíqua se fazia no sentido de emergir, portanto, através do folclore, o caráter nacional do povo brasileiro. Com isso, Mário de Andrade via nesse costume um dos meios para demonstrar o nível de "amadurecimento" no qual se encontrava o Brasil (FERNANDES, 1994). Ao percorrer esse caminho, trazia consigo uma marca que destoava do outro tipo de pensamento em formação anteriormente mencionado.

Segundo Fernandes (1994):

É preciso ressaltar, contudo, a ausência de finalidades chauvinistas (...) Nacional aqui significa expressividade, existência de um padrão característico e próprio de cultura. (FERNANDES, 1994, p. 144).

Desta maneira, a proposta de Mário de Andrade apresentou-se na contracorrente das propostas das elites brasileiras do período, alicerçando na formação da sociedade e buscando suas características culturais específicas, ao invés de pensar o território enquanto uma área a ser "coberta" por uma nação ainda não fundada. Por sua vez, ao se deparar com os contrastes da sociedade e do espaço brasileiros naquele momento, o autor de Macunaíma enfrentou-os como uma questão pessoal! (FERNANDES, 1994). Atuando como o fio condutor das suas questões relativas ao povo e à cultura, o papel do folclore, nesse caso, forneceria o suporte necessário para a expressão do caráter nacional brasileiro. Logo, foi através desse "corte" que Mário de Andrade se propôs a compreender o Brasil. Em suma, "Mário de Andrade propõe criar a arte brasileira como o único modo de ser civilizado" (OLIVEIRA, 1997, p. 191).

Diante desse quadro, o modo como as preocupações se manifestaram nele adquiriram diversos contornos, no entanto possuíam uma base em comum. Na verdade, essa base se consubstanciava na tentativa de superação dos contrastes das diversas realidades do Brasil enquanto espaço e povo, sobretudo este. A respeito disso, Fernandes (1994) assinala:

Trata-se do problema do homem do Brasil (...) [Uma realidade] expressa em quilômetros quadrados e em diferenças regionais agudas - uma realidade sócio-geográfica, pois, digamos, rebarbativamente, que dá uma conformação obrigatória ao problema do homem brasileiro (...) Os antagonismos e as limitações provocaram nele uma reação que é um grito épico de revolta (...) como exigência afetiva e como inquietação - agitada pela falta de sincronização humana de milhares de brasileiros que se ignoram recíproca e simplesmente. Como esta falha de sensação de presença dos homens de nossa terra revela-se sob a forma de conflitos, entre o 'progresso' e o 'atraso', a 'civilização' e o 'interior', é sob este aspecto que Mário de Andrade fixa dolorosamente o problema. (FERNANDES, 1994, p. 145).

De fato, foi justamente através do folclore que o autor de Macunaíma procurou superar a ausência de sincronismo humano e das discrepâncias regionais brasileiras, além dos dilemas da civilização vividos por ele. Entretanto, as particularidades brasileiras, tanto em Mário de Andrade quanto nos pensadores autoritários, foram equacionadas sob duas categorias e que lhes forneceram a base argumentativa para explicar as razões do "atraso" do Brasil: meio e raça.

No mais, resta-nos citar o próprio Mário de Andrade:

De resto e por infelicidade minha, sempre me quis considerar amador em folclore. Disso derivará serem muito incompletas as minhas observações formadas até agora. $\mathrm{O}$ fato de me ter dedicado a colheitas e estudos folclóricos não derivou nunca de uma preocupação científica que eu julgava superior às 
minhas forças, tempo disponível e outras preocupações. Com minhas colheitas e estudos mais ou menos amadorísticos, só tive em mira conhecer com intimidade a minha gente e proporcionar a poetas e músicos, documentação popular mais farta onde se inspirassem. (Mário de Andrade, O Samba Rural Paulista, apud FERNANDES, 1994, p. 153).

\section{O MOVIMENTO MODERNISTA DE 1922}

As expressões literárias, o simbolismo e o parnasianismo, sobretudo este último, correlacionavam-se de maneira assimétrica à simultaneidade dos movimentos no espaço proporcionado pela incipiente modernização técnica no território. Com isso, a necessidade de uma transformação emergia. A constituição de uma nova linguagem que representasse a manifestação dos sentimentos do "homem moderno" diante da paisagem alterada pela técnica - leia-se: industrialização e urbanização - surgia como imperativo essencial:

A industrialização e a urbanização acelerada que, não obstante caóticas e excludentes, mudavam o semblante da cidade e evidenciavam que não era mais possível se exprimir, em termos literários, nos moldes simbolistas e muito menos parnasianos. (CAMARGOS, 2002, p. 48.)

Tal mudança encontra ressonância no "Manifesto Futurista" de Filippo Tommaso Marinetti (1876 - 1944), publicado em Paris no ano de 1909. Exaltando o conceito dinâmico de beleza em associação com o culto à velocidade, os modernistas brasileiros acolheram as inquietações e os sentidos provocados pela tecnologia no início do século XX (CAMARGOS, 2002). Marinetti, em seu manifesto, define os elementos constituintes do Futurismo. Cabe aqui destacar:

Nós declaramos que o esplendor do mundo se enriqueceu com uma beleza nova: a beleza da velocidade.
Um automóvel de corrida com seu cofre adornado de grossos tubos como serpentes de explosivo... Um
automóvel rugidor, que tem o ar de correr sobre a metralha, é mais belo que a Vitória de Samotrácia
(...) É preciso que o poeta se desgaste com calor, brilho e prodigalidade, para aumentar o fervor
entusiástico dos elementos primordiais. Não há mais beleza senão na luta. Nada de obra-prima sem um
caráter agressivo. A poesia deve ser um assalto violento contra as forças desconhecidas, para intimá-las
a deitar-se sobre o homem. Nós estamos sobre o promontório extremo dos séculos!... Para que olhar
para trás, no momento em que desenterrar os batentes misteriosos do Impossível? O Tempo e o Espaço
morreram ontem. Nós vivemos já do absoluto, já que nós criamos a eterna velocidade do onipresente
(...) Nós cantaremos as grandes multidões movimentadas pelo trabalho, pelo prazer ou pela revolta;
as ressacas multicoloridas e polifônicas das revoluções nas capitais modernas; a vibração noturna dos
arsenais e dos estaleiros sob suas violentas luas elétricas; as estações glutonas comedores de serpentes
que fumam; as usinas suspensas nas nuvens pelos barbantes de suas fumaças; as pontes para os pulos
de ginastas lançadas sobre a cutelaria diabólica dos rios ensolarados; os navios aventureiros farejando
o horizonte; as locomotivas de grande peito, que escoucinham os trilhos, como enormes cavalos de
aço freados por longos tubos, e o vôo deslizante dos aeroplanos, cuja hélice tem os estalos da bandeira
e os aplausos da multidão entusiasta. (Marinetti apud. TELES, 1972, p. 66-7).

Todavia, outra de suas diretrizes era:

Nós queremos glorificar a guerra - única higiene do mundo - o militarismo, o patriotismo, o gesto destrutor dos anarquistas, as belas idéias que matam, e o menosprezo à mulher. (Marinetti, apud. TELES, 1972, p. 67).

Nesse sentido, o Futurismo de Marinetti traz consigo, além do culto à velocidade e à máquina, um forte posicionamento de cunho autoritário. Entretanto, a absorção dessas idéias não foi de maneira automática e instantânea pelos modernistas brasileiros. Na verdade, elas exerceram o papel de elemento condutor para a constituição de uma forma de linguagem que trouxesse à tona os sentidos, proporcionados pelas transformações técnicas das metrópoles. Assim, o culto à

Mercator - volume 8, número 17, 2009: set./dez. 
velocidade e à exaltação de uma vida moderna gerada pela máquina encontrou forte eco no Brasil (CAMARGOS, 2002).

A primeira notícia sobre o Futurismo no Brasil se deu através do artigo do escritor português Sousa Pinto, publicado no jornal carioca Correio da Manhã, em 6 de abril de 1909. O escritor caracterizava-o como "sinônimo de doença, desagregação, desequilíbrio e aberração [sendo que] a crítica brasileira ratificaria como o oposto da sobriedade e da harmonia" (CAMARGOS, 2002, p. 37).

Por sua vez, a difusão dessas idéias parece ter encontrado em São Paulo sua maior ressonância. Oswald de Andrade (1890 - 1954) as trouxe após sua primeira viagem à Europa, em 1912, as quais seriam alguns dos elementos iniciais de preparação do modernismo no Brasil.

A partir do encontro de um grupo de intelectuais durante a famosa exposição de Anita Malfatti (1889 - 1964) em São Paulo (12/12/1917 - 10/01/1918), deu-se a intensificação dos debates acerca do Futurismo no Brasil e seus desdobramentos. Considerada o início da etapa preparatória da Semana de Arte Moderna (BOSI, 2003) foi nessa exposição que ocorreu o primeiro encontro dos futuros modernistas: Di Cavalcanti, Guilherme de Almeida, Mário de Andrade, Oswald de Andrade, Ribeiro Couto. Em relação a Mário de Andrade (1893 - 1945), após várias e longas visitas às obras, tornou-se amigo de Anita Malfati. ${ }^{10}$

Alguns anos depois, Oswald de Andrade, a 27 de maio de 1921, publicou o artigo "Meu poeta futurista" no Jornal do Commercio, apresentando Mário de Andrade ao público. Em resposta ao artigo de Oswald, Mário de Andrade publicou o "Futurismo?", a 6 de julho do mesmo ano. ${ }^{11}$ Em seguida, Mário publicou nos meses de agosto e setembro "Mestres do passado", no Jornal do Commercio, repudiando o parnasianismo. A respeito de sua relação com o Futurismo, Mário de Andrade advertia:

Não sou futurista (de Marinetti). Disse e repito-o. Tenho pontos de contato com o Futurismo. Oswald de Andrade, chamando-me de futurista, errou. A culpa é minha. Sabia da existência do artigo e deixei que saísse. Tal foi o escândalo, que desejei a morte do mundo. (Mário de Andrade, Paulicéia Desvairada, apud LUCIA HELENA, 1995, p. 116).

Em relação aos pontos de contato podemos verificar que estes se deram em torno dos signos da tecnologia no início do século passado. Ademais, incorporaram o perfil do jovem agressivo, repleto de entusiasmo, que trazia para si a incumbência de destruir a ordem vigente e compor, ao mesmo tempo, uma nova (CAMARGOS, 2002). Nesse sentido, os modernistas não absorveram tampouco cultivaram, "lato sensu", o princípio marinettiano. Isto se torna mais evidente ao constatarmos o desconforto de Mário de Andrade diante do rótulo "futurista" segundo afirmação de Oswald:

Depois, começaram os escrúpulos, sobretudo da parte de Mário de Andrade. Ele, nacional e nacionalista como era, não se sentia à vontade dentro do rótulo estrangeirante. Assim, pouco a pouco, foi encontrada a palavra 'modernista' que todo o mundo adotou'. (Oswald de Andrade, O modernismo, apud CAMARGOS, 2002, p. 39).

Carregada de ambigüidades e contradições, a palavra "modernista" almejava ser a representação das transformações que aconteciam naquele início de século. Na tentativa de torná-la legítima, a Semana de Arte Moderna de 1922, provida de antagonismos, aspirou ser o ponto de convergência dessas tendências, não apenas artísticas e literárias, mas também de ascensão nacional, sobretudo pelo desejo de conectar o país ao compasso do mundo. Assim, "a semana de 22 pretendia captar a vida em movimento, a eletricidade, o cabo submarino, o automóvel, o aeroplano, o cinema" (Oliveira, L.L., 1997, p. 190). Nesse sentido, os símbolos e os signos da tecnologia, sob o amparo do Futurismo, serviram como fonte inspiradora e como representação do avanço e do progresso. De tal modo que esse momento "se caracteriza pelo combate ao passado, pela elaboração de uma nova estética adequada à vida moderna e pela captação da realidade atual entendida como a vida urbana e industrial que tinha São Paulo seu exemplo máximo" (OLIVEIRA, 1997, p. 190). 
Considerada como ruptura do padrão cultural bacharelesco vigente, a Semana de 22, no entanto, não pode ser encarada como uma "quebra" epistemológica do ponto de vista literário, isto é, como uma espécie de ponto de partida na cultura brasileira (Camargos, M., 2002). Na verdade, a produção dos modernistas procurou abalar toda uma visão de Brasil que trazia no bojo um ataque às atividades da produção literária no final do século XIX e início do XX. (LAFETÁ, 2000).

Em suma, Oliveira (1997) observa:

O modernismo combateu o que existia antes: o romantismo -sentimental, pré-racional, pré-moderno; o realismo - preso ao cientificismo e ao pessimismo (as raças e o clima como um background negativo); o parnasianismo - preso aos cânones rígidos da métrica e da rima. (OLIVEIRA,1997, p. 190).

Além disso, outra marca que a Semana traz consigo é a manifestação contrária aos ufanismos presentes nas comemorações do Centenário da Independência. Aí parece estar sua maior contradição: se por um lado a "Semana" desejava manifestar-se de maneira contrária às comemorações, por outro lado ela também se revelou de modo ufanista, apesar de ambos os movimentos possuírem conteúdos diferentes. O desvanecimento repousava no desejo de ser moderno a qualquer custo (HELENA, 1995). Nesse sentido, uma das trajetórias para atingi-lo parece ter sido a crença no mito positivista do progresso, ou seja, da modernização técnica no território como o elemento condutor ao desenvolvimento econômico, social e cultural:

... o que está em causa é a vinculação direta entre progresso e teleologia: o crescimento técnico determinaria, mecanicamente, o crescimento social, econômico e cultural. Não se consideram as contradições, os movimentos de avanço e recuo nem o caráter não-linear nem a interação assimétrica das várias esferas do social e do político. (HELENA, 1995, p. 107).

Assim, desejava-se transpor o período do movimento de ruptura e continuidade dos processos que estavam ocorrendo naquele momento. Com isso, a modernidade adviria do progresso técnico, isento da necessidade do período de transição em curso.

Outro aspecto em relação à Semana de Arte Moderna de 1922 refere-se aos seus patrocinadores. A arte moderna nasceu no Brasil sob o auspício da parte mais refinada da aristocracia rural. Segundo Camargos (2002) foi patrocinada através da figura de Paulo da Silva Prado (1869-1943), sendo um dos principais, ao lado do escritor e diplomata Graça Aranha (1868 - 1931). Filho do conselheiro Antônio Prado, ${ }^{12}$ sua família possuía grande fortuna e influência à época. A família Prado, de tradicional família de cafeicultores, aplicou parte de seus capitais em bancos, indústrias, ferrovias, mercado imobiliário além de negócios em importação e exportação. Essas atividades proporcionaram enorme êxito econômico, ampliando sua influência e poder políticos, posicionando-o como um dos principais representantes da elite paulista (CAMARGOS, 2002).

Sobre seus aspectos culturais, Lafetá (2000) observa:

Educada na Europa, culturalmente refinada, adaptada aos padrões e aos estilos da vida moderna, não apenas podia aceitar a nova arte como, na verdade, necessitava dela (...) $\mathrm{O}$ aristocratismo de que se reveste precisa ser justificado por uma tradição que seja característica, marcante e distintiva - um verdadeiro caráter nacional que ela represente em seu máximo refinamento. (LAFETÁ, 2000, p. 24).

Enfim, o movimento modernista se caracterizou como mais um das expressões dos grupos sociais brasileiros do período, e que compôs a multiplicidade de forças que estavam se desenrolando no seio da sociedade brasileira da década de 1920. Ademais, provocou conseqüências no debate acerca da cultura brasileira. Sua manifestação é sintomática, pois também se configurou como um dos reflexos do momento de transição - apesar do aparente desejo em transpor-la - que estava ocorrendo na capital paulista, além do contexto internacional vivido pelos participantes da Semana. 


\section{AS VIAGENS ETNOGRÁFICAS DE MÁRIO DE ANDRADE E A DESCOBERTA DO MITO}

Macunaíma - O Herói Sem Nenhum Caráter, de Mário de Andrade é considerada uma das obras mais importantes da literatura brasileira. Publicada em 1928, introduziu uma linguagem completamente inovadora e revolucionária, combinando com as convulsões típicas da sociedade brasileira dos anos de 1920 .

A idéia de compor o texto refere-se ao interesse de Mário de Andrade de descobrir a essência do brasileiro, refletindo uma tendência anterior ao período no sentido de encontrar um "caráter nacional brasileiro", tema já clássico do trabalho de Dante Moreira Leite (1983).

O que me interessou por Macunaíma foi incontestavelmente a preocupação em que vivo de trabalhar e descobrir o mais que possa a entidade nacional dos brasileiros. Ora depois de pelejar muito verifiquei uma coisa que me parece certa: o brasileiro não tem caráter... E com a palavra caráter não determino apenas uma realidade moral não, em vez entendo a entidade psíquica permanente, se manifestando por tudo nos costumes na ação exterior no sentimento na língua na História na andadura tanto no bem como no mal. O brasileiro não tem caráter porque não possui nem civilização própria nem consciência tradicional. (LEITE, 1983,p.15).

Macunaíma inscreve-se no período em que predominou o Modernismo na arte brasileira. O termo Modernismo, na verdade, é atribuído a Mário de Andrade, numa expressão clara de sua intenção de criar um conceito de arte própria ao Brasil, ainda que acompanhando um movimento internacional. $\mathrm{O}$ futurismo, o dadaísmo, o expressionismo e o surrealismo, movimentos artísticos europeus naqueles tempos, estão presentes nessa obra marcante, no entanto, essas expressões artísticas são vistas pelo autor do ponto de vista da Antropofagia, ou seja, como uma forma de absorver as tendências internacionais no que elas apresentam de interessante. Ademais, a obra foi também resultado de um estudo profundo sobre os mitos, as lendas, o folclore de várias regiões brasileiras.

Desta maneira, despertado pelo desejo de conhecer o Brasil, Mário de Andrade realizou duas "viagens etnográficas": uma em 1927, com destino ao Nordeste e Norte do Brasil, e a outra em 1928, ao Nordeste. A primeira viagem surgiu a partir da idéia de um grupo vinculado ao modernismo de São Paulo. No início o grupo era formado por: Afonso de Taunay, Mário de Andrade, D. Olívia Guedes Penteado e Paulo Prado.

Integrantes de um cortejo oficial comunicado pelo governo do Estado de São Paulo à época ao governo de outros Estados, Mário estava animado, pois era a chance de conhecer e realizar suas pesquisas sobre as raízes nacionais. Entretanto, no dia do embarque alguns dos membros desistiram, causando uma certa decepção no escritor. Assim, os responsáveis pela excursão foram: Dulce (filha de Tarsila do Amaral), Magnólia Nogueira e sua tia D. Olívia Guedes Penteado e Mário de Andrade.

Percorreram boa parte do litoral brasileiro e da Amazônia chegando até Iquitos, no Peru (único momento de sua ausência do território brasileiro). Dessa viagem resultou o diário "O Turista Aprendiz" ( $1^{\text {a }}$ parte) e um fortalecimento no intercâmbio de idéias com os modernistas do Norte e do Nordeste. O interesse de Mário de Andrade nessa viagem - e também na outra - estava em conhecer o Brasil através do povo e suas expressões: costumes, danças, cantos, modos de vida etc. Nesse sentido, o que caracterizou o registro da viagem foi a fotografia. Segundo Lopez (1972) o volume de fotos tiradas pelo escritor foi de aproximadamente 540, todas detalhadas, com hora, data, local, participantes.

Em 1928, realizou a segunda "viagem etnográfica", desta vez para o Nordeste, sozinho, a convite de amigos de lá, entre os meses de dezembro e fevereiro do ano seguinte. ${ }^{13}$ Lá coletou documentos musicais: danças dramáticas, músicas de feitiçaria etc, além de fotografar também: "A segunda viagem etnográfica faz com que Mário de Andrade encontre o NE como o coração do Brasil, não atingido ainda pela mecanização negada com veemência em Macunaíma" (LOPEZ, 1972, p. 147).

Nas figuras 1 e 2 constam os itinerários das "viagens etnográficas" de Mário de Andrade: 


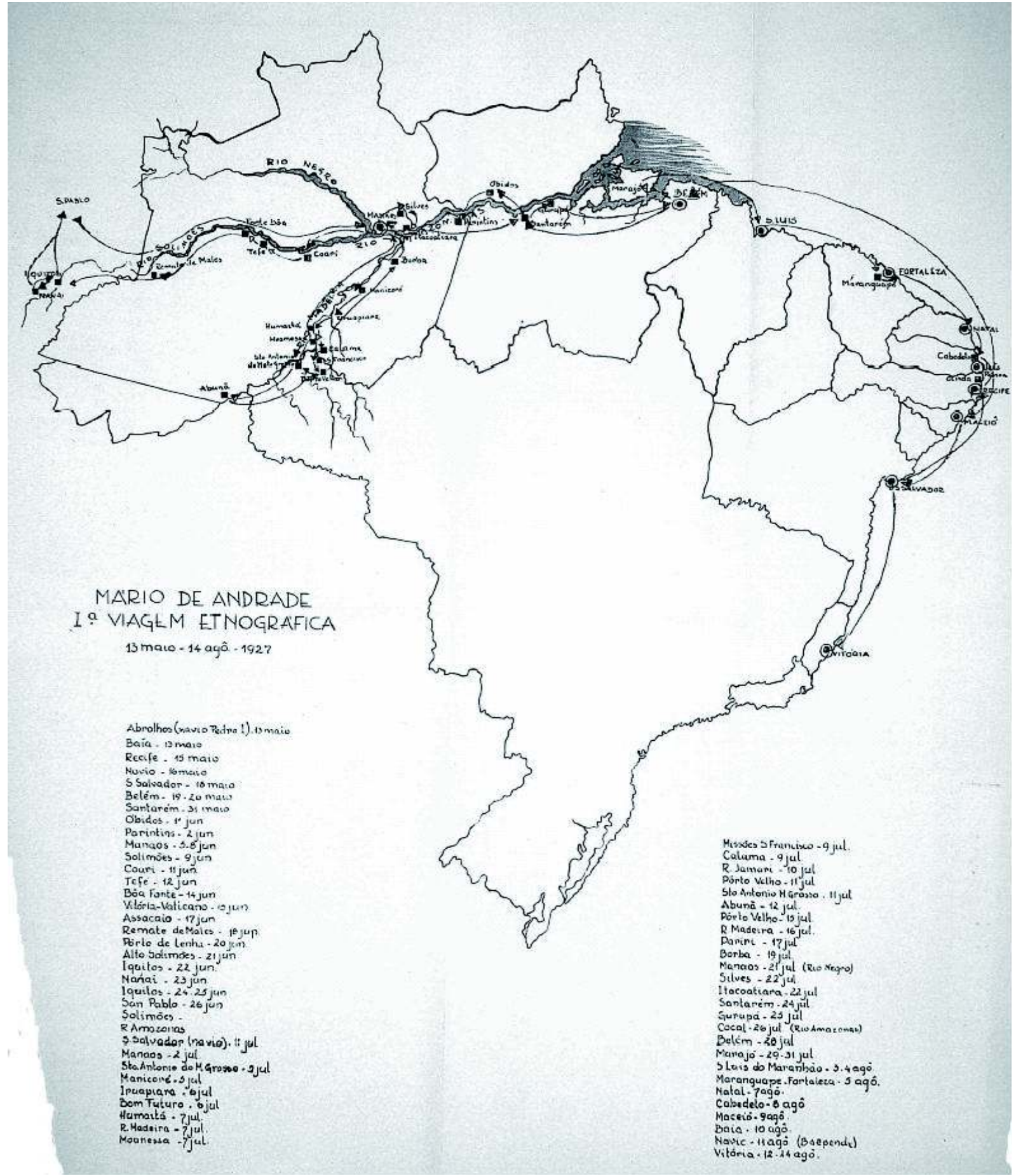

Figura 1 - Itinerários das Viagens Etnográficas de Mário de Andrade I

Fonte: LOPEZ, Telê Porto Ancona. "Viagens Etnográficas de Mário de Andrade: itinerário fotográfico". Revista do Instituto de Estudos Brasileiros, n 11, São Paulo, IEB-USP, 1972. 


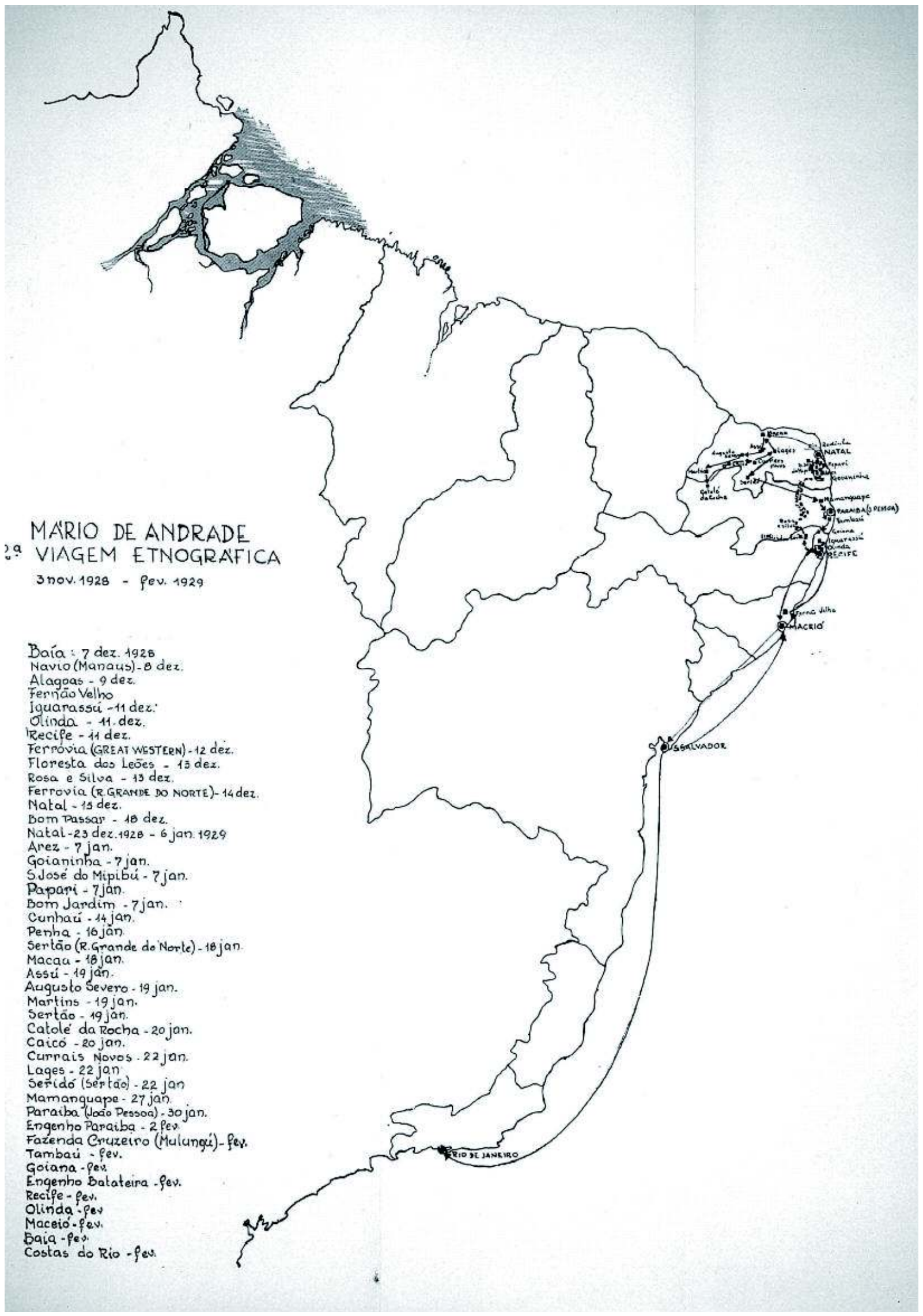

Figura 2 - Itinerários das Viagens Etnográficas de Mário de Andrade II

Fonte: LOPEZ, Telê P. A. "Viagens Etnográficas de Mário de Andrade: itinerário fotográfico". Revista do Instituto de Estudos Brasileiros, n 11, São Paulo, IEB-USP, 1972. 
Impulsionado também pelo debate caloroso a respeito da nacionalidade brasileira, na medida em que realizava suas viagens pelo Brasil reunia também expressões a respeito do modo de falar, do folclore, dos costumes indígenas, inclusive de frutas, bichos e comida como podemos notar em algumas passagens de Macunaíma:

... respeitava os velhos e freqüentava com aplicação a murua a poracê o torê o bacorocô a cucuicogue, todas essas danças religiosas da tribo. (ANDRADE, 2001, p. 13).

Jiguê viu que a maloca estava cheia de alimentos, tinha pacova tinha milho tinha macacheira, tinha aluá e cachiri, tinha marapas e camorins pescados, maracujá-michira ata abio sapota sapotilha, tinha paçoca de viado e carne fresca de cutiara, todos esses comes e bebes bons... (ANDRADE, 2001, p.22)

O jacareúna o jacaretinga o jacaré-açu o jacaré ururau de papo amarelo (...) Nos ramos das ingazeiras das aningas das mamoranas das embaúbas dos catauaris de beira-rio o macaco prego o macaco-de-cheiro o guariba o bugio o cuatá o barrigudo o coxiú o cairara, todos os quarenta macacos do Brasil (...) E os sabiás, o sabiacica o sabiapoca o sabiúna o sabiá piranga o sabiagongá que quando come não me dá, o sabiá-barranco o sabiá tropeiro o sabiá-laranjeira o sabiá-gute. (ANDRADE, 2001, p.40)

Ao chegar à cidade de São Paulo, em busca de sua muiraquitã, o herói sem nenhum caráter escreve uma carta aos seus pares distantes contando suas impressões e descrevendo a fisionomia da capital paulista à luz do início do século XX, como podemos notar abaixo:

É São Paulo construída sobre sete colinas, à feição tradicional de Roma, a cidade cesárea,'capita', da Latinidade de que provimos; e beija-lhe os pés a grácil e inquieta linfa do Tietê. As águas são magníficas, os ares tão amenos quanto os de Aquisgrana ou de Anverres, e a área tão a eles igual em salubridade e abundância, que se bem podera afirmar, ao modo fino dos cronistas, que de três AAA se gera espontaneamente a fauna urbana. (ANDRADE, 2001, p.66).

Cidade é belíssima, e grato o seu convívio. Toda cortada de ruas habilmente estreitas tomadas por estátuas e lampiões graciosíssimos e de rara escultura; tudo diminuindo com astúcia o espaço de forma tal que, nessas artérias não cabe a população" (ANDRADE, M., 2001, p.77). ${ }^{14}$

Numa fala que remete aos "críticos" brasileiros mais severos, como um Gregório de Matos (1636-1695), Mário de Andrade transmite através de Macunaíma, uma visão sobre o Brasil que grita pela necessidade de transformação profunda. Parafraseando Saint-Hilaire, para quem "Ou o Brasil acaba com a saúva ou a saúva acaba com o Brasil", o herói sem caráter anuncia uma frase que resume a posição do País naquele momento: "Pouca saúde e muita saúva, os males do Brasil são"(ANDRADE, 2001,p.51).

Para além do dístico vale destacar o contexto em que o mesmo aparece no texto:

Tudo vai num descalabro sem comedimento, estamos corroídos pelo morbo e pelos miriápodes! Em breve seremos novamente uma colônia da Inglaterra ou da América do Norte!... Por isso e para eterna lembrança destes paulistas, que são a única gente útil do país, e por isso chamados de Locomotivas, nos demos ao trabalho de metrificarmos um dístico, em que se encerram os segredos de tanta desgraça... (ANDRADE, 2001, p. 79).

A Amazônia tida como o símbolo das forças locais (e não exatamente nacionais) reage diante do moderno representado, sobretudo por São Paulo, e Macunaíma (Imperator das Icamiabas ${ }^{15}$ cede mediante os encantos da cidade. Sua morte é simbólica da derrota do local perante o estrangeiro, da fraqueza das culturas locais perante a cultura ocidental erudita. Não basta o diletantismo de Macunaíma perante a força maior que se instala, a partir do litoral. 
Araújo (2002/2003) destaca a contradição em que está envolvido o autor de Macunaíma:

a relação de Mário de Andrade com o tempo e com o espaço é contraditória em sua essência. Essa contradição reside na coexistência de um sentimento nostálgico e de uma ansiedade com relação ao futuro, contradição que se reveste de uma dimensão geográfica na medida em que traduz em uma oposição entre espaços simbólicos singulares. Se o sentimento nostálgico, no sentido aqui expresso, finca raízes nas imagens amazônicas, a ansiedade do futuro faz de São Paulo um dos grandes motes temáticos do poeta (ARAÚJO, 2002-2003, p.50).

A proposta de nação colocada em Macunaíma faz-nos pensar a respeito de qual projeto está sendo explicitado pelo autor na obra. Se um projeto dele próprio para o Brasil ou se o projeto que vem se efetivando nesses anos. A contradição destacada por Araújo é valida quando tomada a primeira situação em que a idéia de uma nação brasileira confunde-se com a proposta desejada pelo autor, entretanto, se Mário tinha a intenção de mostrar e argumentar sobre o que efetivamente vinha ocorrendo em termos das escolhas que se davam em meio ao embate da sociedade, essa contradição não é pessoal; quiçá nem mesmo uma contradição.

Ao transpor o país como se não houvesse barreiras de espaço e nem de tempo - uma vez que o texto dialoga com personagens nos mais variados tempos históricos -, a mensagem deixada é a de que o território abrange a nação desejada e a de que a história é de todo o povo residente nesse espaço territorial:

Nem todos estavam informados sobre a extensão espacial dessas alterações, porém muitos dos indivíduos alfabetizados bem poucos na época, foram sensíveis à idéia de progresso tão rápido quanto materialmente possível (...) A mudança na relação com o tempo, bem-vinda por alguns, era temida por outros, que a entendiam como um novo fator de diferenciação social e espacial que iria agravar as diferenças já existentes. Para muitos deles, o tempo, indício e signo de mudanças maiores futuras, foi contraposto ao espaço, expressão de permanência para uns, e de inércia para outros. Por isso, nas questões, nos termos em que foram sendo colocados os debates, nas propostas dos indivíduos cujas idéias foram sendo valorizadas ou descartadas, o espaço geográfico era uma realidade e também uma metáfora para expressar outros interesses e realidades.(MACHADO, 1995, p.311).

Desta maneira, as proposições em história do pensamento geográfico têm se avolumado nos últimos anos através de vários fronts. Um dos mais ricos, sem dúvida, concentra-se junto à literatura. Entretanto, este ainda se apresenta como o grande desafio para os pesquisadores interessados em desbravar a construção de um pensamento geográfico no Brasil.

Se entendermos por pensamento geográfico o "conjunto de discursos a respeito do espaço que substantivam concepções que uma dada sociedade, num momento determinado possui acerca de seu meio (desde o local até o planetário) e das relações com ele estabelecidas" (MORAES, 1988, p.32), torna-se evidente a possibilidade de que a literatura seja um de seus veículos, talvez um dos mais importantes.

Várias manifestações de um tempo são transmitidas através dos textos literários, de maneira extremamente particular - uma vez estes estando ligados à arte. Desta forma, o escritor é visto como um intelectual de seu tempo. Escrevendo sobre o cotidiano ou não, sua produção é carregada das necessidades, preocupações, possibilidades dos homens com os quais convive.

Segundo Goldmann (1985)

... apesar de o indivíduo só raramente possuir uma consciência realmente completa da significação e da orientação de suas aspirações, seu sentimento e seu comportamento, não é menos verdade que ele possui sempre uma consciência relativa. De vez em quando, alguns indivíduos excepcionais chegam a alcançar a coerência integral. Na medida em que conseguem expressá-la, no plano conceitual ou na imaginação, são filósofos ou escritores e sua obra é tanto ou mais importante quanto mais se aproxima 
da coerência esquemática de uma concepção de mundo, quer dizer, o máximo possível de consciência do grupo social que expressam. (GOLDMANN, 1985, P.29).

Não se pode negar as dificuldades envolvidas numa empreitada que procura dar conta de levantar a máxima consciência possível numa obra de cunho artístico e que, não raras vezes, pretende fugir de seu mundo, de seu tempo. Nesse sentido, a concepção de espaço pode ser "vista como processo teleológico, sustentado em projetos e guiados por concepções" (MORAES, 2000, p.17), na qual a idéia de brasilidade estaria pautada, assim, no discurso presente no livro. Tal interpretação torna-se possível ao assimilarmos o território amparado pelo aspecto cultural, cuja apropriação e qualificação "inscreve-se no campo dos processos de identidade societária, como referente de formas de consciência do espaço e, mesmo, de autoconsciência grupal (nos grupos que se identificam pela relação com um dado espaço)" (MORAES, 2000, p. 21).

A avaliação de "Macunaíma - o herói sem nenhum caráter", apresenta-se como um aporte imprescindível para a compreensão do pensamento geográfico no Brasil tendo em vista a idéia de consciência do espaço na obra. Nesse sentido, o papel da literatura nesse período contribuiu eficazmente no desenho de uma consciência nacional por meio de pesquisas sobre o modo de vida e espaço brasileiros (CÂNDIDO, 1975).

A idéia de modernidade transmitida pelo autor e de seu embate com as tradições locais brasileiras, no início do século XX, é bastante representativa das questões pertinentes à formação nacional brasileira, em cujo seio vê-se o peso do recorte territorial. Assim, a proposta de Mário de Andrade apresenta-se na contracorrente das propostas das elites brasileiras do período, alicerçando-se na formação da sociedade e buscando suas características culturais específicas, ao invés de pensar o território enquanto uma área a ser "coberta" por uma nação ainda não fundada.

Macunaíma e a identidade nacional.

Para Mário de Andrade, a beleza está na subjetividade. No interior desta se encontra o subconsciente, fonte de toda a riqueza e individualidade, cujo aporte imprescindível para atingi-lo é a sensibilidade. Logo, toda reflexão de seu pensamento estético está calcada nos pares indivíduosociedade, consciente-inconsciente, ser-parecer, lirismo-técnica (SCHWARZ, 1981).Nesse sentido, como indicativo das diversas atitudes, são apresentadas três posições:

1. uma posição individualista, na qual a presença da técnica ${ }^{16}$ é mínima (fonte de todo o lirismo);

2. uma posição antiindividualista, cuja significação social se dá por meio da técnica (instrumento para se construir a nacionalidade); e,

3. uma tentativa de elaboração de uma técnica pessoal (para todo lirismo específico - nível do subconsciente individual - há uma técnica - nível do consciente).

A atitude individualista, em Mário de Andrade, é marcada pelo subjetivismo cuja manifestação se dá por meio dos versos e rimas livres. Desta forma, o lirismo é exteriorizado por meio da subconsciência e auxiliado pela forma de escrever a poesia desprovida de qualquer lógica ou regra normativa e, conseqüentemente, os momentos de subconsciência ganham importância e precisam ser respeitados. No entanto, ao adotar esta posição a poesia fica reduzida a ela própria, registrando-a àquilo que já foi vivido e tornando-a absolutamente descomprometida com o imaginário.

Segundo Schwarz (1981), busca-se a verdade, a sinceridade e, conseqüentemente, ela perde toda a sua especificidade, pois é posta no mesmo patamar da verdade psicológica. A postura de Mário de Andrade nessa primeira atitude é a de que não há superação dos pares dialéticos, ou seja, não existe a possibilidade de ser técnico e lírico simultaneamente; individualista e político; consciente e subconsciente. Para ele, são superações inconcebíveis, pois se trata de posições absolutas, portanto, indivisíveis. 
$\mathrm{Na}$ segunda atitude, o antiindividualismo, que nos interessa mais diretamente, ganha corpo uma preocupação nacionalista. Essa preocupação advém da postura individualista da intelligentzia brasileira, face ao novo quadro social. Porém, o subconsciente não é posto de lado por Mário de Andrade. O subconsciente mantido como fonte geradora de vida, necessita de controle por meio da técnica, pois a ausência dela é assimilada como destruidora e anti-social.

Se o subconsciente era visto anteriormente como algo necessário, agora é visto como fora de controle e que precisa ser "domado". Contudo, o aspecto mais curioso nessa atitude, segundo Schwarz (1981), é a presença sutil do irracionalismo devido à falta dos pares dialéticos em seus conceitos. Desta forma, há uma mudança de ênfase, porém a situação é mantida. É deixada de lado a verdade psicológica para ater-se ao que é inteligível e social. A poesia assume propósitos, dentre eles a idéia de nacionalismo, cuja finalidade estaria no auxílio de construir uma tradição, gerando a necessidade, assim, de cultura e estudo nos conteúdos dos poemas. Nesse sentido, a técnica assume o papel de conferir à sensibilidade uma nova forma de expressão. Portanto, é no interior dessa atitude que podemos verificar algumas das razões que levaram Mário de Andrade a escrever Macunaíma.

Como indicativo dessa atitude, Machado (1995) reforça:

"Nem todos estavam informados sobre a extensão espacial dessas alterações, porém muitos dos indivíduos alfabetizados bem poucos na época, foram sensíveis à idéia de progresso tão rápido quanto materialmente possível (...) A mudança na relação com o tempo, bem-vinda por alguns, era temida por outros, que a entendiam como um novo fator de diferenciação social e espacial que iria agravar as diferenças já existentes. Para muitos deles, o tempo, indício e signo de mudanças maiores futuras, foi contraposto ao espaço, expressão de permanência para uns, e de inércia para outros. Por isso, nas questões, nos termos em que foram sendo colocados os debates, nas propostas dos indivíduos cujas idéias foram sendo valorizadas ou descartadas, o espaço geográfico era uma realidade e também uma metáfora para expressar outros interesses e realidades".(MACHADO, 1995, p.311).

O rompimento dos arquipélagos regionais e a natureza na constituição da identidade nacional.

Macunaíma pode ser considerado como sendo a tentativa de Mário de Andrade de integrar a produção cultural brasileira no solo da nação. Para isto, procurou rever a história do Brasil e integrála em um projeto de Brasil (MORAES, 1978).

Para isto, Mário de Andrade irá circunscrever a nacionalidade brasileira em sua dimensão física, em sua dimensão geográfica, enquanto critério de enraizamento cultural e literário em contraposição à cultura oficial das elites desenraizadas, alienadas pela adoção de uma crítica de empréstimo. Para tanto, haverá a construção do sentimento nacional como estratégia de se construir o sentimento de uma comunidade imaginada e compartilhada.

Segundo Moraes (1978) a estratégia de Mário de Andrade será utilizar a proposta de Euclides da Cunha, que em sua obra os Sertões redefiniu o desenho geográfico do Brasil, pois buscou no sertão, região que até então estava além dos limites da civilização, a identidade nacional.

O imaginário territorial (MORAES, 1998, 2002b)) torna-se possibilidade essencial para a constituição do sentimento de comunidade imaginária. Para Moraes (1978:82), “ considerou-se também a integração, através da busca de inspiração material do país, sua opulência e a exaltação da terra brasileira. Existe também a integração mais ampla dos elementos díspares presentes na realidade brasileira".

Macunaíma transitará entre a literatura, a etnologia e a cultura popular, procurando construir uma identidade nacional homogênea a partir de um redesenho geográfico do país pautado no folclore indígena, caboclo e sertanejo. Macunaíma personificará e corporificará com suas incaracterísticas um ideal humanístico de absorção de paradoxos, buscando sintetizá-los a partir de uma dimensão maravilhosa que redesenha o corpo da nação, o que o próprio Mário de Andrade chamou de "desgeografização" (ANDRADE, 1993, 2000). Mais do que uma figura literária ou estilística, Mário de Andrade expressa aqui um conceito geográfico e exprime a necessidade de rompimento dos arquipélagos mercantis e culturais que ainda formavam a arquitetura do território nacional e que em sua visão impedia a construção de uma identidade nacional. 
Isto porque Macunaíma é um personagem essencialmente espacial, que em seu percurso maravilhoso traduz a busca de uma "libere mesmo as forças escondidas da nação, os antagonismos entre presente e passado, modernização e atraso, campo e cidade, eruditismo e saberdoria popular (MORAES, 1978, p.85).

Macunaíma, a identidade do Brasil é construído a partir do manejo simbólico da Geografia. Não é sem sentido que a apresentação da narrativa se inicia pelo núcleo mítico do racismo pseudocientífico, ainda profundamente arraigado nos debates sobre a identidade nacional (GALVÃO, 1998, p.29), na região longínqua do Uraricoera, completamente apartada da civilização, de onde Macunaíma parte em direção ao litoral. Não é a toa que na primeira frase do primeiro parágrafo de toda a narrativa está em primeiro plano a caracterização do lugar soturno, isolado e despovoado da procedência do "herói de nossa gente": " no fundo do mato-virgem nasceu Macunaíma, herói de nossa gente. Era preto retinto e filho do medo da noite. Houve um momento em que o silêncio foi tão grande escutando o murmurejo do Uraricoera, que a índia tapanhumas pariu uma criança feia. Essa criança é que chamamos Macunaíma" (ANDRADE, 1987, p.7).

Gilda de Mello e Souza (SOUZA, 1979) não vê na trajetória macunaímica uma progressão, mas pelo contrário, divisa um personagem ambivalente, dúbio e indeciso. Para ela, Macunaíma não é uma personagem que progride em sua trajetória pelo tempo e pela ação do espaço. É uma personagem que oscila constantemente sem resolver as contradições que se refletem principalmente no espaço e também no tempo, nas características do personagem que, por sua vez, está irremediavelmente disperso entre orientações contrárias. Ao contrário, Macunaíma não está preso a uma fixação de caráter, pois as suas contradições se resolvem no espaço. É um herói por que configurase espacialmente e não temporalmente como os demais heróis. É na dinâmica espacial do herói que Mário de Andrade procura resolver as contradições e o antagonismo. É neste momento que se procura construir a identidade brasileira.

Para Gilda de Mello e Souza, esta postura está muito bem representada na vingança de Vei. "O epsódio, no entanto, não constitui apenas a discussão figurada da tese central do livro; mas de certo modo resume e antecipa o longo debate sobre a identidade nacional, que nunca mais abandonará a reflexão atormentada do escritor" (SOUZA, 1979, p.63).

Urariocera é o sítio da procedência do herói. Como ressalta o narrador na apresentação, o "fundo do mato virgem" é um lugar inóspito e isolado da civilização. É uma região desértica, de miséria e fome, de enfrentamentos, traições e competições entre Macunaíma e seus familiares, de disputas sexuais sangrentas entre o herói e seus irmãos e de violentos confrontos com a própria mãe. É deste espaço hostil de seu nascimento que o herói vai partir com seus irmãos, depois da morte da mãe, para escapar da fome e para onde vai voltar, no final, para ser arruinado e morto. O espaço é reflexivo das características oscilantes do herói e compartilham de sua duplicidade de sentido, assim como a trajetória percorrida depois da partida de Uraricoera.

Proença (1974, p.11) considera que Macunaíma é um personagem incaracterístico que não está na ordem do bem e nem na ordem do mal, não é nem ingênuo e muito menos esperto, nem moral e nem imoral, e não pode ser julgado pela hierarquia de valores ocidentais. As margens do Uraricoera, de onde procede o herói, é um fundo de mato inexplorado pelo homem civilizado, uma vez que era de uma tribo tapanhuma. Índio e negro, é miscegenado pelas raças mais inferiores aos olhos das teorias racistas eurocêntricas do início do século XX, morando num fundo de mato virgem, isolado da civilização. A questão racial, no segundo período modernista, ainda provocava um intenso debate sobre a identidade nacional e é do mito racial e do deserto inculto que a narrativa parte.

A metamorfose de Macunaíma em formiga e sua volta à forma humana precedem o início do processo de "des-geografização". No outro dia, depois de "brincar" bem cedo com Iriqui, ele sai para dar um pequeno passeio: "Saiu para dar uma voltinha. Atravessou o reino encantado da Pedra Bonita em Pernanbuco e quando estava chegando na cidade de Sanarem topou com uma viada parida" (ANDRADE, 1987, p.19). 
Essa excursão de Macunaíma é relevante, pois ele cai em uma emboscada de Anhangá, deus protetor do campo e da caça, e pensando estar perseguindo uma veada, acaba matando sua própria mãe. Esse fato é o motivo da partida do herói das margens do Urarioeca acompanhado do irmão e de sua cunhada, dando crescente fôlego ao processo de "des-geografização", configurando a visão de mundo da obra e sua reflexão sobre a brasilidade. A partida do herói e seus companheiros abandonando o "fundo do mato virgem" em direção à metrópole paulistana, traduz o dilema da passagem da natureza para a cultura, do atraso da selva para o progresso urbano e do transcurso da origem autêntica para a adoção da postura postiça da civilização.

Chama à atenção o fato de Vei, a sol, acompanhar todas as andanças desgeografizadas do herói. Nessa trajetória ela serve como elo entre o personagem, o fundo do mato virgem de onde procede e a metrópole de São Paulo, bem como todos os demais itinerários percorridos por Macunaíma. Dessa forma, exerce, enquanto elemento permanente, de contraponto a toda a trajetória espacial da narrativa, simbolizando um elemento tropical estável no desenho geográfico.

As andanças de Macunaíma são processos de baralhamento geográfico, realizando um trânsito rapsódico entre os mitos brasileiros em suas origens e suas fontes de Portugal, indígenas e africanas. O desarranjo espacial, a tese da unidade do território e a necessidade do fim dos arquipélagos, é revelada por meio de uma tensão dialética não só entre as origens míticas, mas também entre o local nacional e o universal europeu. Revela-se nisso a natureza transitante dos mitos brasileiros que, em 1947, Luís Câmara Cascudo assim definiu: “ os nossos mitos são de movimento, de ambulação, porque recordam os velhos períodos dos caminhos, dos rios, das bandeiras, de todos os processos humanos de penetração e vitória sobre a distância (CASCUDO, 1947, p.62).

Macunaíma, a obra, é um bricolagem de lendas sertanejas, caboclas, caipiras e indígenas tornadas tensas com figurações míticas de origem européia, algumas inclusive medievais, para a partir daí descobrir uma definição da identidade nacional homogênea e totalizante. Para tanto não pode haver uma brasilidade parcial ou um sentidonacional, gravitando em torno do imaginário exótico europeu. Para Câmara Cascudo (1947) Mário de Andrade procurou estabelecer o elo entre os "vasos comunicantes" (p. 62) que ligariam dinamicamente as diversas culturas regionais, fornecendo assim um importante suporte folclórico que pusesse em tensão criativa e dialeticamente a cultura nacional fundada no primitivo, com possibilidades de incorporação na civilização internacional. A atuação de Macunaíma é a tentativa de superar as contradições e encontrar um ponto de equilíbrio em que fosse possível atenuar as supostas diferenças regionais, barreiras para a formação de um sentido nacional que expressasse a idéia de comunidade coletiva e compartilhada, e encontrar uma expressão totalizante em um plano mais profundo.

A “des-geografização" ou se quisermos nos expressar de uma outra forma, o rompimento do arquipélagos regionais, permitiria a construção da nação brasileira, em que o folclore e os mitos forneceriam o amálgama para a construção social do brasileiro e de sua cultura que lhe garantiria o sentido do pertencimento e o sentimento simbólico e cultural da nação.

\section{CONSIDERAÇÕES FINAIS}

A análise do pensamento geográfico na obra Macunaíma, de Mário de Andrade, instiga-nos a pensar na metáfora espacial e nos argumentos geográficos que moldam a construção da nação. A reflexão espacial que transforma a terra, a natureza, em cognição de um mundo brasileiro em uma sociedade historicamente marcada pela busca da modernidade, sem entender o significado próprio do que é ser moderno, mas que sempre elegeu, independente da época histórica, o estrangeiro, como moderno.

Uma imaginação periférica que tanto moldou a intelectualidade nacional, que cristalizou uma tradição, em menor grau, mas ainda presente nos dias atuais, e, que moldam as ideologias geográficas, ainda hoje, cujo tema é a inserção do Brasil na globalização, a relação centro-periferia, enfim, um projeto civilizatório, que como uma esfinge, nos interroga constantemente. 
O tema espacial ao longo das décadas sempre esteve presente na imaginação social brasileira, permitindo a invenção simbólica e técnica das imagens espaciais, que são fruto de um complexo intercruzamento entre os determinismos geográficos, a experimentação técnica-tecnológica, os cientificismos e a importação dos modelos estrangeiros.

Portanto, o imaginário geográfico brasileiro configura-se como uma trama complexa de contextos e textos que projeta a nossa sociabilidade e a institucionalização do espaço geográfico como um mecanismo pragmático e simbólico de construção da nação e de seu movimento político.

A natureza, a terra, são elementos naturais moldados culturalmente, transformados culturalmente que se transformam em paisagem, que no imaginário social, transforma-se em metáfora, criando espaços e fronteiras imaginárias, por onde circulam lendas, mitos, concepções políticas e diferentes narrativas civilizatórias. Assim, em muitos projetos civilizatórios, as paisagens e os ciclos da natureza foram utilizados como mecanismo impulsionador da marcha cultural e domínio das naturezas. Exemplos podem ser encontrados em Simon Schama (SCHAMA, 1996) e em Richard Bartlett (BARTLETT, 1974), quando relatam, por exemplo, que no imaginário norte-americano, o relevo ocupou sempre um lugar de destaque na metáfora espacial, onde os protestantes viam nas diferenças morfoclimáticas a possibilidade de purificação moral e espiritual. Outro elemento natural importante na construção do imaginário nacional norte-americano, foram as árvores, no caso as sequóias e os carvalhos, onde a comparação entre o ciclo da natureza e o do sacrifício em ocupar a terra era imediato, e as árvores eram simbolicamente compreendidas como dádivas de deus, os as sequóias e os carvalhos eram entendidas como um ato de liberdade e divindade que funcionariam como um cimento no projeto civilizacional norte-americano.

Em Macunaíma, também a natureza e a metáfora espacial é invocada para a construção da nacionalidade e da identidade brasileira, mas ao contrário dos intelectuais que advogavam o caráter inóspito da natureza e a moral degradada do brasileiro, Mário de Andrade, via aí, a potencialidade para construção de uma nação alegre, livre e democrática. Macunaíma é uma ideologia geográfica que preza pela desconstrução do mito e do símbolo europeu, onde a tese da desgeografização é fundamental para a construção espacial e para o fortalecimento da identidade nacional brasileira. Pois, conforme era dado o arranjo espacial brasileiro, demonstrando um claro atrelamento e subserviência à Europa e aos USA, representada na metáfora espacial pela dialética dos dois Brasis e da contradição litoral-interior.

A fronteira, não deve mais ser concebida como o limite da civilização, mas como a potencialidade de construção simbólica e geográfica de um país e de uma nação, como um sentimento íntimo que re-liga o povo entorno de uma utopia.

Outra metáfora espacial que liga as ideologias geografias ao projeto nacional em Macunaíma, é que a identidade nacional é um processo construído a partir de contradições entre o homem e a natureza, onde constantemente, em nossa rapsódia sintetizamos essa contradição em diferentes arranjos espaciais.

Há um paradoxo geográfico em Macunaíma, pois não ter caráter é estar desalojado de toda e qualquer predeterminação que impedem o homem e a nação de experimentar as possibilidade e as potencialidade de ser o construtor cotidiano de sua identidade. Assim, a cultura brasileira, historicamente construída na relação homem-natureza, redesenha a representação espacial do Brasil, onde o local e o universal convivem e potencializam relações dialógicas entre as várias culturas e naturezas. A estética da nação e sua identidade está na diversidade cultural e na diferenciação geográfica.

Acreditamos ser essa, uma abordagem interessante para a geografia e por que não, para a própria geografia física brasileira, onde a investigação histórica e a construção de modelos de relevo, clima, vegetação, rios, montanhas, e, paisagem, poderia se realizar a partir de um profundo e complexo contato com antropologia cultural e com a etnografia. 


\section{NOTAS}

(1) A respeito da matriz do romantismo brasileiro, Ortiz (2006) faz uma observação: “... o modelo que se utiliza para pensar a sociedade brasileira é o da Idade Média. Nisso, o nosso romantismo se diferencia pouco do romantismo europeu, que se volta para o passado glorioso para entender o presente" (ORTIZ, R., 2006, p. 37).

(2) Já no final do século XIX e adentrando no século XX é possível verificar uma sensível mudança no âmbito da discussão da identidade e nacionalidade brasileiras. Dentre os exemplos, cabem destacar as figuras de Euclides da Cunha (1866 - 1909), com Os Sertões, e Silvio Romero (1851 - 1914).

(3) Ver: DINIZ FILHO, L.L., "O determinismo ambiental na formação do pensamento político autoritário brasileiro". Revista RA’EGA - O espaço geográfico em análise. Ano VI, n 6. Curitiba: Editora UFPR, 2002.

(4) Sobre os estudos da realidade brasileira Diniz Filho (2002) observa: “... nesse contexto discursivo aparecia como importante catalisador das teses deterministas" (DINIZ FILHO, L. L., 2002, p. 19).

(5) Durante esse período, o principal veículo de divulgação da política cultural do regime era a revista Cultura Política, publicada pelo Departamento de Imprensa e Propaganda (DIP). Nela, é possível verificar também a influência das teses deterministas nos discursos de Getúlio Vargas (DINIZ FILHO, L. L., 2002).

(6) A respeito desses moldes, Lahuerta (1992) assinala: "a exigência de modernização que movimentou as energias da sociedade ao longo dos anos 20 não tinha um sentido muito definido. Afinal, se é verdadeiro que a intelectualidade passa a pensar o país, procurando-o, propondo reformas e a construção de uma nação moderna, há que se fazer a ressalva de que tudo isso ocorre de maneira muito ambígua. No fundo, a pressão por racionalidade técnica era no Brasil ainda muito incipiente, já que a ciência continuava a não coordenar de fato - e nem mesmo como ideologia - nosso real” (LAHUERTA, M., 1992, p. 32).

(7) Todavia, há de se fazer a ressalva que o movimento modernista não envolveu apenas as figuras de Mário de Andrade, Oswald de Andrade e o grupo ligado a eles, estreitamente ligado a uma "revolução na literatura" (Lafetá, J. L., 2000), mas também figuras como Cassiano Ricardo, Menotti Del Picchia e Plínio Salgado. Assim, ao mencionar os outros "contornos" acerca da nacionalidade brasileira a partir do movimento modernista estou me referindo ao modo como se manifestou, especificamente, em Mário de Andrade - considerando-o como um dos mentores do modernismo no Brasil - em comparação com a concepção autoritária que estava se desenhando após a Semana de 1922.

(8) FERNANDES, Florestan. "Mário de Andrade e o folclore brasileiro", Revista do Instituto de Estudos Brasileiros, $\mathrm{n}^{\circ} 36$, São Paulo, IEB-USP, 1994, pp. 141-158.

(9) Sobre o modo como Mário de Andrade realizava essa inversão, Fernandes (1994) assinala: "As duas artes defrontam-se numa relação dialética - tal como Mário de Andrade situa o problema: a arte erudita deve realizar-se na e através da arte popular - e a antítese, no caso a arte popular, cede o lugar a uma terceira forma de arte que do ponto de vista da fatura chama-se ainda arte erudita, mas que é uma coisa nova, mais essencial e mais expressiva (...) trata-se da realização da arte erudita e não do seu nivelamento à arte popular" (FERNANDES, F., 1994, p. 147).

(10) Sobre a relação de amizade entre ambos ver: ANDRADE, Mário de. Mário de Andrade: cartas a Anita Malfati. Organizada por Rosseti Batista. Rio de Janeiro: Forense Universitária, 1989.

(11) Segundo Camargos (2002), o conteúdo do artigo é marcado pela reprovação do emprego de rótulos estéticos e pelo estabelecimento de sua própria pesquisa sobre a modernidade.

(12) À época, o conselheiro Antonio Prado era o exemplo de cafeicultor, comerciante e industrial simultaneamente (CARONE, E., 1969).

(13) Macunaíma é publicado em maio de 1928.

(14) Muito desses termos que foram mencionados não são possíveis de serem encontrados no dicionário, pois muitos deles já desapareceram.

(15) “É bem verdade que na boa cidade de São Paulo, não sois conhecidas por 'icamiabas', voz espúria, sinão que pelo apelativo de Amazonas. E de vós se afirma cavalgardes ginetes belígeros e virdes da Hélada clássica, e assim sois chamadas". (MACUNAÍMA - O herói sem nenhum caráter, p.71)

(16) A técnica a qual nos referimos é a da escrita.

\section{REFERÊNCIA BIBLIOGRÁFICA}

ANDRADE, Mário de. Mário de Andrade: cartas a Anita Malfati. Organizada por Rosseti Batista. Rio de Janeiro: Forense Universitária, 1989.

ANDRADE, Mário de. Macunaíma: o herói sem nenhum caráter. 14 ed., São Paulo: circulo do livro, 1987. 
ANDRADE, Mário de. Macunaíma: o heroi sem nenhum caráter. Texto revisto por Telê Ancona Lopez, Belo Horizonte, Rio de Janeiro: livraria Garnier, 2000.

ANDRADE, Mário de. Macunaíma: o herói sem nenhum caráter. 32 edição. Texto revisto por Telê Porto Ancona Lopez. BH/RJ: Livraria Garnier, 2001. (Col. Autores Modernos da Literatura Brasileira).

ANDRADE, Mário de. Vida Literária. São Paulo: Edusp/Hucitec, 1993.

ARAUJO, R. Do Sertão aos Pampas: o território da Literatura Nacional no Século XX. Terra Brasilis, Anos III e IV, n.4-5. Rio de Janeiro: Território, 2002-2003.

ARRIGHI, G. O Longo Século XX. RJ/SP: Editora Contrponto/Editora da Unesp, 1993.

BARTLETT, R.A. The new country: a social history of the American frontier, 1776-1890. Londres: Oxford University Press, 1974.

BOSI, A. Dialética da Colonização. SP: Companhia das Letras, 2003.

CAMARGOS, Márcia. Semana de 22: entre vaias e aplausos. São Paulo: Boitempo Editorial, 2002.

CANDIDO, A. Literatura e Cultura de 1900 a 1945. In: . Literatura e Sociedade. 4 ed. SP:Companhia Editora Nacional, 1975.

CARAONE, E. A Primeira República (1889-1930). SP: Difusão Européia do Livro, 1969.

CASCUDO, Luís Câmara. Geografia dos mitos brasileiros. Rio de Janeiro: José Olympio, 1947.

DE LORENZO, Helena Carvalho \& COSTA, Wilma Peres da. (orgs.). A década de 20 e as origens do Brasil Moderno. São Paulo: Edunesp, 1997. (Prismas).

DINIZ FILHO, L.L., O determinismo ambiental na formação do pensamento político autoritário brasileiro. Revista RA'EGA - O espaço geográfico em análise. Ano VI, nº 6. Curitiba: Editora UFPR, 2002, pp.7-45. FERNANDES, Florestan. Mário de Andrade e o folclore brasileiro. Revista do Instituto de Estudos Brasileiros, n 36, São Paulo, IEB-USP, 1994, pp. 141-158.

GOLDMANN, L. Dialética e Cultura. RJ: Civilização Brasileira, 1985.

HELENA, Lúcia. Sobre a história da Semana de 22. In: MALLARD, Letícia [et. al.]. História da Literatura: ensaios. Campinas: Editora da UNICAMP, 1995.

LAFETÁ, João Luiz. 1930: a crítica e o Modernismo. São Paulo: Duas cidades; Editora 34, 2000.

LAHUERTA, M. Elitismo, Autonomia, Populismo. Os intelectuais na transição dos anos 40. Campinas: Instituto de Filosofia e Ciências Humanas da Unicamp, 1992 (Dissertação de Mestrado).

LOPEZ, T.P.A. Viagens Etnográficas de Mário de Andrade. Revista do Instituto de Estudos Brasileiros, n.7, SP:IEB-USP, 1969.

LOPEZ, T.P.A. Viagens Etnográficas de Mário de Andrade: Itinerário fotográfico. Revista do Instituto de Estudos Brasileiros, n.11, SP:IEB-USP, 1972.

MACHADO, Lia Osório. Origens do pensamento geográfico no Brasil: meio tropical, espaços vazios e a idéia de ordem (1870 - 1930). In: CASTRO, Iná Elias de; GOMES, Paulo César da C.; CORRÊA, Roberto L. Geografia: conceitos e temas. Rio de Janeiro: Bertrand Brasil, 1995.

MORAES, Antonio Carlos Robert. Ideologias Geográficas. SP: Hucitec, 1988.

MORAES, Antonio Carlos Robert. Bases da Formação Territorial do Brasil: o território colonial brasileiro no longo século XVI. SP:Hucitec, 2000.

MORAES, Antonio Carlos Robert. História do pensamento geográfico no Brasil: indicações. Revista Geografares, $\mathrm{n}^{\circ}$ 3, Vitória, Departamento de Geografia da Universidade Federal do Espírito Santo, junho de 2002a, pp. 151-158.

MORAES, Antonio Carlos Robert. Território e História no Brasil. São Paulo: Hucitec, 2002b.

MORAES, Eduardo Jardim . A brasilidade modernista: sua dimensão filosófica. Rio de Janeiro: Graal, 1978.

MORAES, Eduardo Jardim . Limites do moderno: o pensamento estético de Mário de Andrade. Rio de Janeiro: Relume Lumará, 1999.

OLIVEIRA, Lúcia Lippi. Questão nacional na Primeira República. In: DE LORENZO, Helena Carvalho \& COSTA, Wilma Peres da. (orgs.). A década de 20 e as origens do Brasil Moderno. São Paulo: Edunesp, 1997. (Prismas).

Mercator - volume 8, número 17, 2009: set./dez. 
ORTIZ, Renato. Cultura brasileira e identidade nacional. São Paulo: Brasiliense, 2006.

PROENÇA, M.C. Roteiro de Macunaíma. RJ: Civilização Brasileira, 1974.

SOUZA, Gilda de Mello e . O tupi e o Alaúde: uma interpretação de Macunaíma. São Paulo: Duas Cidades, 1979.

SCHAMA, S. Paisagem e Memória. SP: Companhia das Letras, 1996.

SCHWARZ, Roberto. O psicologismo na Poética de Mário de Andrade. In:

A Sereia e o Descon-

fiado. RJ: Paz e Terra, 1981, 2 ed., (coleção Literatura e Teoria Literária, v. 37).

SCHWARZ, Roberto. Nacional por Subtração. In: Que horas são? São Paulo: Companhia das Letras, 1997.

TELES, Gilberto Mendonça. O Futurismo. In: Vanguarda européia e modernismo brasileiro. Rio de Janeiro: Vozes, 1972.

VIANNA, L.W. A Revolução Passiva. RJ:Editora Revan, 2001.

Trabalho enviado em setembro de 2009

Trabalho aceito em dezembro de 2009 